\title{
Source of strontium in archaeological mobility studies-marine diet contribution to the isotopic composition
}

\author{
Maria Lahtinen ${ }^{1,2,3}$ D $\cdot$ Laura Arppe ${ }^{2} \cdot$ Geoff Nowell $^{4}$ \\ Received: 4 June 2020 / Accepted: 13 November 2020 / Published online: 5 December 2020 \\ (C) The Author(s) 2020
}

\begin{abstract}
The strontium isotope composition of human tissues is widely used in archaeological mobility studies. However, little attention is paid to the relative contributions of terrestrial versus marine sources of strontium in these studies. There is some debate over the role of a solid diet versus drinking water as the most important source of strontium for the human body, with related possibilities of misinterpretation of the archaeological record if only strontium isotope compositions of the biosphere are studied. However, there is a third component, marine strontium, which is commonly not assumed to contribute towards the strontium isotope composition of archaeological skeletal remains, especially in locations that are not directly coastal. To illustrate the potentially obfuscating effects of mixed $\mathrm{Sr}$ sources in a human population, we present a case study of twelve individuals from the medieval Finnish site Iin Hamina with a known dietary history. Our study shows that marine consumption is a significant factor explaining the strontium isotope composition of the Iin Hamina human remains, with implication of erroneous conclusions about immigration without prior knowledge of diet composition. Thus, future studies should always incorporate a rigorous analysis of dietary history, with special regard to potential consumption of aquatic resources, when strontium isotope analysis is used as a method in the study of palaeomobility.
\end{abstract}

Keywords Diet $\cdot$ Mobility $\cdot$ Strontium isotope $\cdot$ Medieval $\cdot$ Iin Hamina $\cdot$ Finland $\cdot$ Strontium isotope analysis

\section{Introduction}

Where did Ötzi "the iceman" originate (Muller 2003)? Were the skeletal remains discovered in Britain really those of King Richard III (Lamb et al. 2014)? What was the level of mobility of early farmers in the Balkans (Borić and Price 2013)? These are all big questions in archaeology where the strontium isotope $\left({ }^{87} \mathrm{Sr} /{ }^{86} \mathrm{Sr}\right)$ method has been used to solve mysteries. This fundamental methodology in archaeology has given many answers to questions regarding the origin of people and objects, even though many potentially important aspects of strontium metabolism are not completely understood. Most

Maria Lahtinen

maria.lahtinen@finnishfoodauthority.fi

Finnish Food Authority, Helsinki, Finland

2 Finnish Museum of Natural History, University of Helsinki, Helsinki, Finland

3 Department of Archaeology, University of Turku, Turku, Finland

4 Department of Geosciences, Durham University, Durham, UK applications of the method assume that all strontium derives from the terrestrial environment and ultimately from the local bedrock and hence can be used as a tracer for humans and animals. Here we show that in a seemingly terrestrial setting, fish or other marine dietary items can substantially affect the strontium isotope composition of human skeletal material, to the extent that they might be interpreted as non-locals. This can be seen as a strong correlation between skeletal strontium isotope composition, and $\delta^{13} \mathrm{C}$ and $\delta^{15} \mathrm{~N}$ values reflecting the level of use of marine/freshwater resources. These results suggest that more focus should be directed at studying the source of strontium when results are being used to estimate the origins and mobility of people, particularly in environments where substantial use of aquatic dietary resources is likely but also in areas with more limited but possible use. One method is to use $\delta^{13} \mathrm{C}$ - and $\delta^{15} \mathrm{~N}$-based diet reconstructions from the same skeletal material.

Strontium isotope analysis is widely used in archaeology for migration studies (Ericson 1985; Bentley 2006; Montgomery 2010; Price et el. 1986; Sillén and Kavanagh 1982). It is thought to be a relatively straightforward method, as the strontium isotope composition of bone and enamel 
reflects the consumed strontium isotope composition of the diet. Consumed strontium is assimilated into the calcified tissues because of its similar properties and behaviour with calcium, which enables it to replace calcium in the bone mineral structure. While mass-dependent metabolic fractionation of $\mathrm{Sr}$ isotopes does occur, i.e. the isotopic composition changes between different trophic levels (Fietzke and Eisenhauer 2006), it is so small scale that most instruments cannot determine it, and furthermore, any tiny fractionation effects are eliminated by internationally agreed normalization protocols. Thus, we can approximate that bone and enamel strontium isotope compositions directly reflect the sources of strontium in the environment (Capo et al. 1998).

It is yet undetermined whether the $\mathrm{Sr}$ signatures recorded by human bones are more dominated by $\mathrm{Sr}$ input from drinking water or diet. Because nuclear tests increased the concentration of atmospheric radioactive strontium-90 in the 1950s, strontium metabolism and bone chemistry in humans were studied intensively after the tests. While these medical studies have targeted Sr-90 due to its harmful properties, the results provide insight into the overall sources of strontium to the human body. A study conducted on New Yorkers revealed that the majority of their strontium derives from vegetables, cereal grains and dairy products and not from water (Klusek 1984). Contrary to this, in the Tesha Riversite case in current Russia, both foodstuffs and water contributed to human strontium intake, and there, the main strontium source was estimated to be drinking water (Tolstykh et al. 2011).

Strontium is mainly absorbed through the gastrointestinal tract into the human body (Apostoaei 2002). Due to its similarity, $\mathrm{Sr}$ can substitute $\mathrm{Ca}$ in the skeletal carbonate hydroxyapatite, but calcium is strongly prioritized during incorporation from blood plasma to bone. Strontium incorporation into bone is not only proportional to its concentration in the diet but particularly to the strontium-to-calcium ratio $(\mathrm{Sr} / \mathrm{Ca})$ of the diet. Dietary items with a certain concentration of strontium combined with high calcium abundance (relatively low $\mathrm{Sr} / \mathrm{Ca}$ ) contribute less to bone strontium than items of similar $\mathrm{Sr}$ concentration but with lower calcium abundance (i.e. higher $\mathrm{Sr} / \mathrm{Ca}$ ratios; Burton and Wright 1995). It is also likely that there are other yet unknown mechanisms, which can influence the absorption of trace elements, like $\mathrm{Sr}$, from different foodstuffs. For example, it is a generally recognized fact that vitamin D promotes the absorption of calcium in the human body. This begs the question of whether also the strontium of vitamin D-rich foods is generally more efficiently incorporated in body tissue, perhaps leading to bone ${ }^{87} \mathrm{Sr} /{ }^{86} \mathrm{Sr}$ signatures biased towards vitamin D-rich foodstuffs like high-fat marine fish. In summary, it seems plausible that the overall dominant source of $\mathrm{Sr}$ to the body varies depending on several interconnected factors, including characteristic concentrations of $\mathrm{Sr}$ and $\mathrm{Ca}$ in the local bedrock, surface waters and the terrestrial biosphere, and the type of staple dietary items of the population.
This study focuses around the concern that in provenance studies of ancient populations or individuals where no direct information on the diet is available, a lack of knowledge on the potential sources of $\mathrm{Sr}$ can potentially lead to significant misinterpretation. This is true especially in regions where bioavailable strontium of varying isotopic ratios is present in very unevenly distributed concentrations, making it more likely for one source to dominate over the others and push the Sr isotope compositions of the local inhabitants away from the (arithmetic) mean $\mathrm{Sr}$ isotope value expected for the area. However, diet and mobility can be studied by combining light stable isotope methods to ${ }^{87} \mathrm{Sr} /{ }^{86} \mathrm{Sr}$ analyses to increase our understanding of the potential strontium sources of the studied individual. We present a case study of such a situation from the Fennoscandian Shield with its generally low calcium bioavailability, high terrestrial baseline ${ }^{87} \mathrm{Sr} /{ }^{86} \mathrm{Sr}$ variability and location close to the seashore. Our aim is to evaluate the influence of diet composition-examined through $\delta^{13} \mathrm{C}$ and $\delta^{15} \mathrm{~N}$ analysis from dentine - on the ${ }^{87} \mathrm{Sr} /{ }^{86} \mathrm{Sr}$ values observed in a population of humans.

\section{The site}

The Iin Hamina site is situated in Northwestern Finland (Northern Ostrobothnia; Fig. 1) at the shore of river Ii. The river is famous for its abundant salmon, and it is likely to have served as a significant source of sustenance to people also in the past. Another good source for fish and seals is the Baltic Sea. The current distance to the Baltic Sea is approximately $6 \mathrm{~km}$. However, at the time of use of the site, the Baltic Sea Shore was closer due to the ongoing post-glacial land uplift constantly increasing the distance to the coast. The Baltic Sea sub-basin closest to the site is called the Bothnian Bay. The site is one of the largest medieval period cemeteries discovered and excavated in Finland. Based on coins found at the site and radiocarbon datings of bone collagen, it dates from the fifteenth to the sixteenth century AD (Kallio-Seppä 2011; Lahtinen and Salmi 2019). Information about this period from Northern Ostrobothnia is sparse, and contrary to overall small findings from the area, the Iin Hamina site contains skeletal material from at least 260 individuals. The skeletal material is well preserved, making it the optimal material for isotope studies (Lahtinen 2017; Lahtinen and Salmi 2019; Lahtinen et al. 2013; Kallio-Seppä et al. 2010).

Fig. 1 a Simplified bedrock and $\mathbf{b}$ topsoil $(1 \mathrm{~m})$ maps (based on data obtained from the Geological survey of Finland), c modelled ${ }^{87} \mathrm{Sr} /{ }^{86} \mathrm{Sr}$ distribution of bedrock in the study area based on Kaislaniemi (2011), d location of site. Numbered dots in panel a indicate the sampling points of plants analysed for ${ }^{87} \mathrm{Sr} /{ }^{86} \mathrm{Sr}$ (see Table 1 for data). Stars indicate the location of the site and the river Ii is visible on all maps 


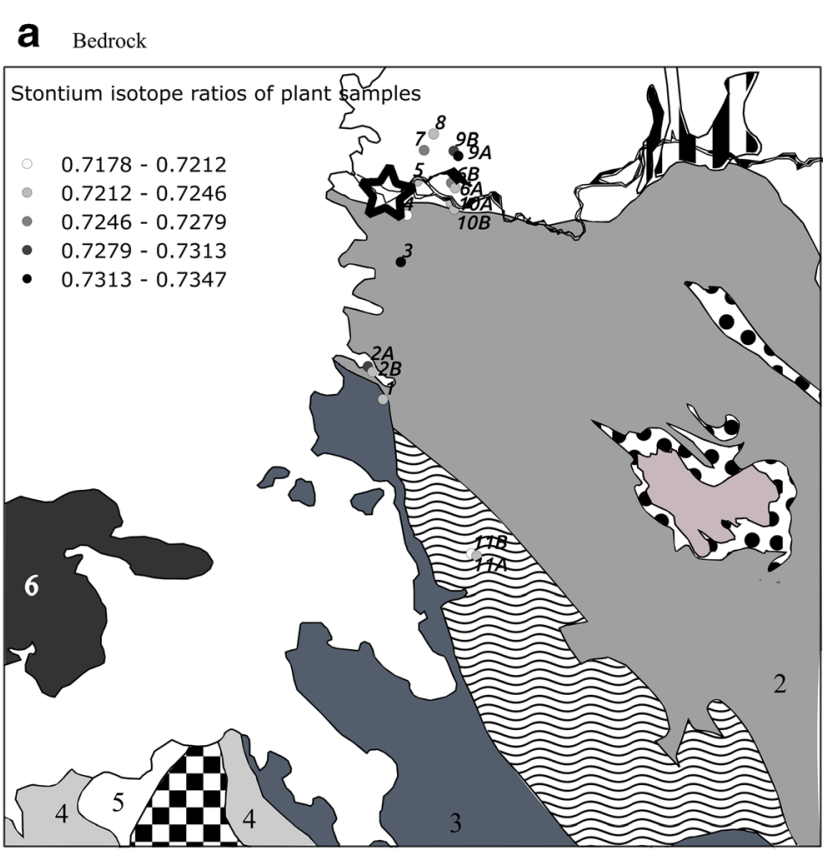

Age (Period), rock type, Domain Archean

$\square$ Archean, Leucocratic granite and granodiorite

ID Archean, Tonalite-trondhjemite-granodioritic gneiss and migmatite

Proterozoic, Karelian Domain

2 Mafic and felsic metavolcanic rocks

$\because \because-=\quad$ Quartzite,

Granite and granodiorite with gneissic inclusions,

Arkosite, mica schist and conglomerate

Proterozoic, Svecofennian Domain

3 Siltstone and shale

4 Mica gneiss and mica schist with intercalated carbonate rocks

E-7.7 Proterozoic, Granodiorite, tonalite and quartz diorite, Svecofennian Domain

5 Gneissic tonalite and granodiorite

C Modelled strontium isotope distribution

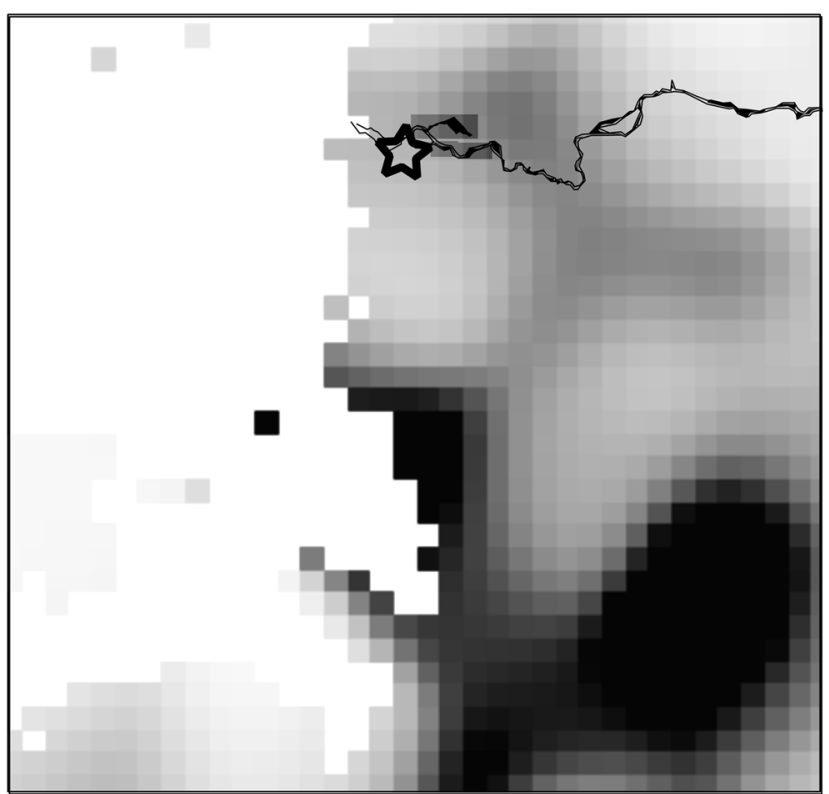

b Soil
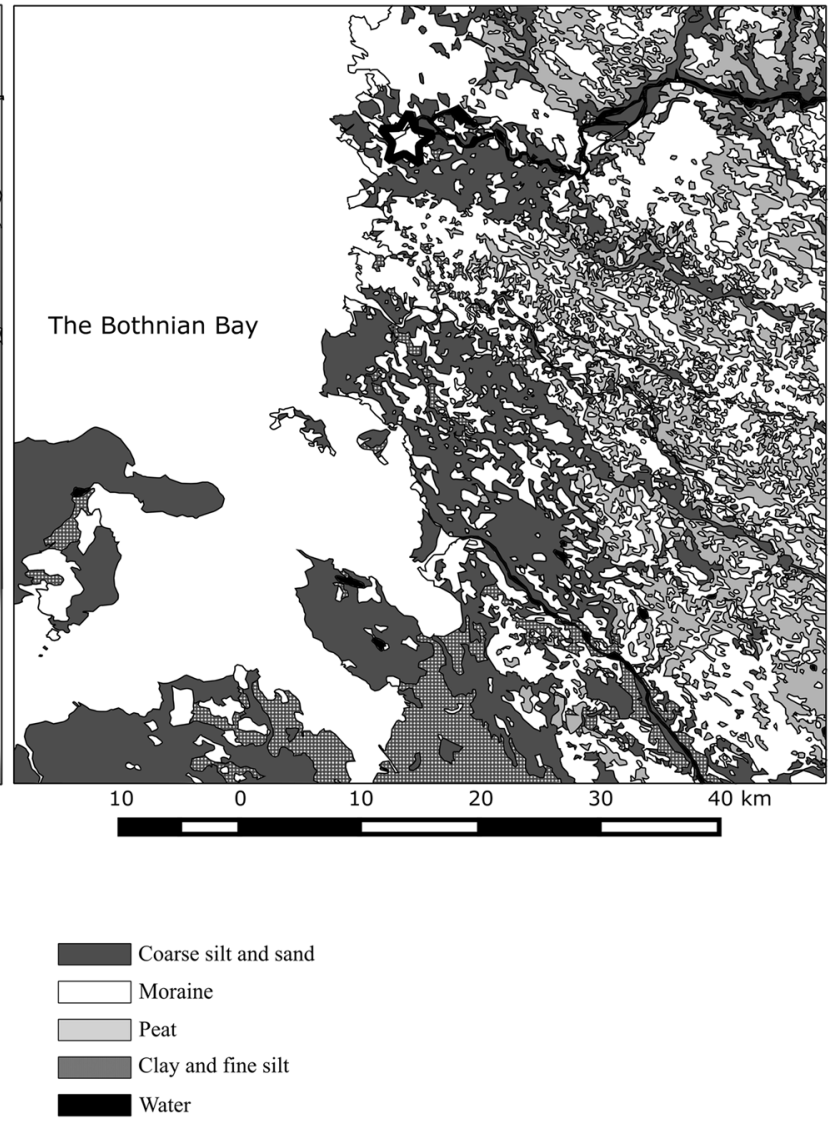

d Location

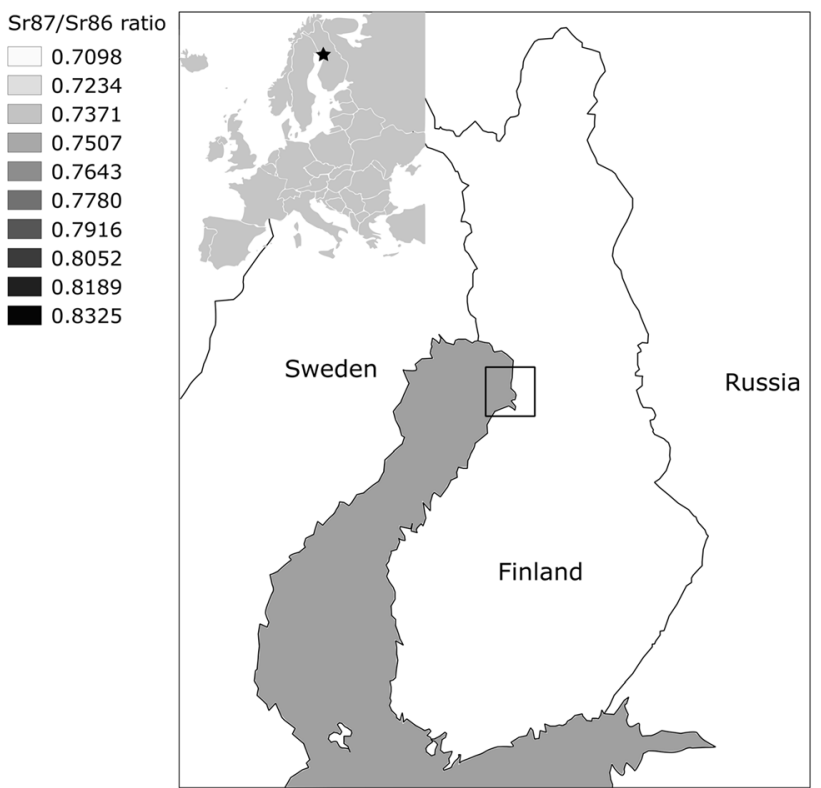


The first historical records indicate that a chapel was erected in Ii during the later half of the fourteenth century AD (Vahtola 1998). However, the location and use of this chapel is unknown and during the later periods, chapels have been erected at seasonal market places (Kylli 2005, 2012). Thus, it could indicate that the location was used as a market, and it has been assumed to indicate possible settlements (Tanska 2011). The site was excavated mainly during the rescue excavation in 2009 (Kallio-Seppä 2010). The site included mainly burials with no artefacts, having a minimum number of individuals at 290. The artefacts discovered from the site include 13 coins, a seal tooth pendant, a cross pendant, a lead bullet (which is suspected not to relate to the burials) and fragments of window glass (Kallio-Seppä 2010).

The diets of the people buried at the site have been intensively studied previously using the carbon and nitrogen isotopic composition analysis of bone and dentine collagen (Lahtinen 2017; Lahtinen and Salmi 2019). The main protein source was estimated to be marine and freshwater fish and based on serial sampling, it remained very constant during the lifetime of studied individuals. We have no supporting historical documentation from the period, but diet substantially based on fish was very typical during later historical times in the area of the whole northern Baltic Sea (Linderholm et al. 2008; Bergman and Ramqvist 2018). Unfortunately, fish bones have not been documented on sites close to the Iin Hamina.

\section{${ }^{87} \mathrm{Sr} /{ }^{86} \mathrm{Sr}$ background}

The ${ }^{87} \mathrm{Sr} /{ }^{86} \mathrm{Sr}$ ratio of bedrock is mainly controlled by three factors: the age of the formation, the initial ${ }^{87} \mathrm{Sr} /{ }^{86} \mathrm{Sr}$ ratio and rubidium abundance of its minerals. The bedrock in Northern Ostrobothnia consists of siliciclastic, metamorphic or plutonic rocks belonging to Archaic (2700 to 2800 million years old), Proterozoic (1900 to 2500 million year old) and Ectasian (old. Jotnian, 1200 to 1400 million years) formations. These old rock types have high ${ }^{87} \mathrm{Sr} /{ }^{86} \mathrm{Sr}$ ratios compared to younger sedimentary rocks, such as those found in for example Estonia, Denmark and Southern parts of Sweden. The ${ }^{87} \mathrm{Sr} /{ }^{86} \mathrm{Sr}$ ratios of the bedrock around the Iin Hamina region have been modelled as highly variable, with compositions ranging from 0.7098 to 0.8325 (Fig. 1; (Kaislaniemi 2011)). A recent modelling study of the bioavailable ${ }^{87} \mathrm{Sr} /{ }^{86} \mathrm{Sr}$ ratios in soils for Northern Europe suggests probable values closer to the lower end ( 0.715) as more likely (Hoogewerff et al. 2019).

The Baltic Sea is a brackish water sea, and its ${ }^{87} \mathrm{Sr} /{ }^{86} \mathrm{Sr}$ ratio in the centre of the Bothnian Bay was measured at $0.709572( \pm$ 0.000024) (Andersson et al. 1992). The river Ii shows a $\mathrm{Sr}$ isotope ratio of $0.73047( \pm 0.000073)$ (Löfvendahl et al. 1990; F. Åberg and Wickman 1987). The Ii river water and the Bothnian Bay have a very low concentration of strontium, being estimated below $20 \mathrm{ppb}(20 \mu \mathrm{g} / \mathrm{l})$ and $23 \mathrm{ppb}(23 \mu \mathrm{g} / \mathrm{l})$, respectively (Löfvendahl et al. 1990; G. Åberg et al. 1990; Löfvendahl et al. 1990; F. Åberg and Wickman 1987).

\section{Materials and methods}

To estimate the local bioavailable terrestrial $\mathrm{Sr}$ isotope baseline values, sixteen plant samples were collected from the region around the Iin Hamina site (see Fig. 1) at the end of May 2014 and analysed for their ${ }^{87} \mathrm{Sr} /{ }^{86} \mathrm{Sr}$ ratios. Sampling sites were selected to include plants growing on top of various sediment formations, different bedrock types and sediments around the site. We selected two plant types: leaves from lingonberry (Vaccinium vitis) which is rooted in the top surface soil and leaves of birch (Betula sp.) which takes up water and nutrients also from deeper soil horizons. In the absence of these two plant species, other plants such as grasses or rowan (Sorbus sp.) leaves were collected (Table 1). At five localities, samples of two different plant types (e.g. leaves of trees and shrubs) were collected, within $1 \mathrm{~m}$ from each other.

Tooth enamel samples $(n=12)$ from ten individuals from the Iin Hamina human skeletal material were selected according to bulk bone collagen isotope composition results of $\delta^{13} \mathrm{C}$ and $\delta^{15} \mathrm{~N}$ analyses performed in a previous study by Lahtinen and Salmi (2019). Samples were selected to represent various collagen isotope compositions and thus reflecting a varied range of diets. The tooth enamel of the selected individuals were analysed in this study for their ${ }^{87} \mathrm{Sr} /{ }^{86} \mathrm{Sr}$ ratios (see Table 1). Issues of preservation precluded the sampling of the same anatomical element, i.e. same tooth type for every individual, and both 2 nd and 3rd molars were included. Both are generally recognized as forming in later childhood/adolescence, after the period of breastfeeding. A section of enamel across the entire height of the crown from the side of each tooth was removed to match the temporal representation of the crown dentine samples.

Enamel was removed from the tooth with a handheld drill, and its surface was cleaned mechanically by drilling away the top surface. Homogenized subsamples of 8-20 mg were dissolved into $0.5 \mathrm{M} \mathrm{HCl}$. Plant samples were left to dry at room temperature, ground and oxidized with ultrapure $\mathrm{H}_{2} \mathrm{O}_{2}$ and $\mathrm{HNO}_{3}$ treatments. Samples were processed in class 100 extraction cabinets and Machaire class fume hood. From both sample types, strontium was collected using strontiumspecific resin with ion-exchange column chemistry (after Charlier et al. 2006).

Samples were analysed at Durham University, Department of Earth Sciences with a Thermo Fisher Neptune multicollector inductively coupled plasma mass spectrometer (MC-ICP-MS). The NBS 987 standard was analysed alongside unknowns and a mean value of 0.7103 with a standard deviation of $0.000009(2 \sigma)$ was obtained. Because of fractionation in analysis, results were normalized to ${ }^{86} \mathrm{Sr} /{ }^{88} \mathrm{Sr}$ ratio of 0.1194 (Nier 1938; Steiger and Jäger 1977). 


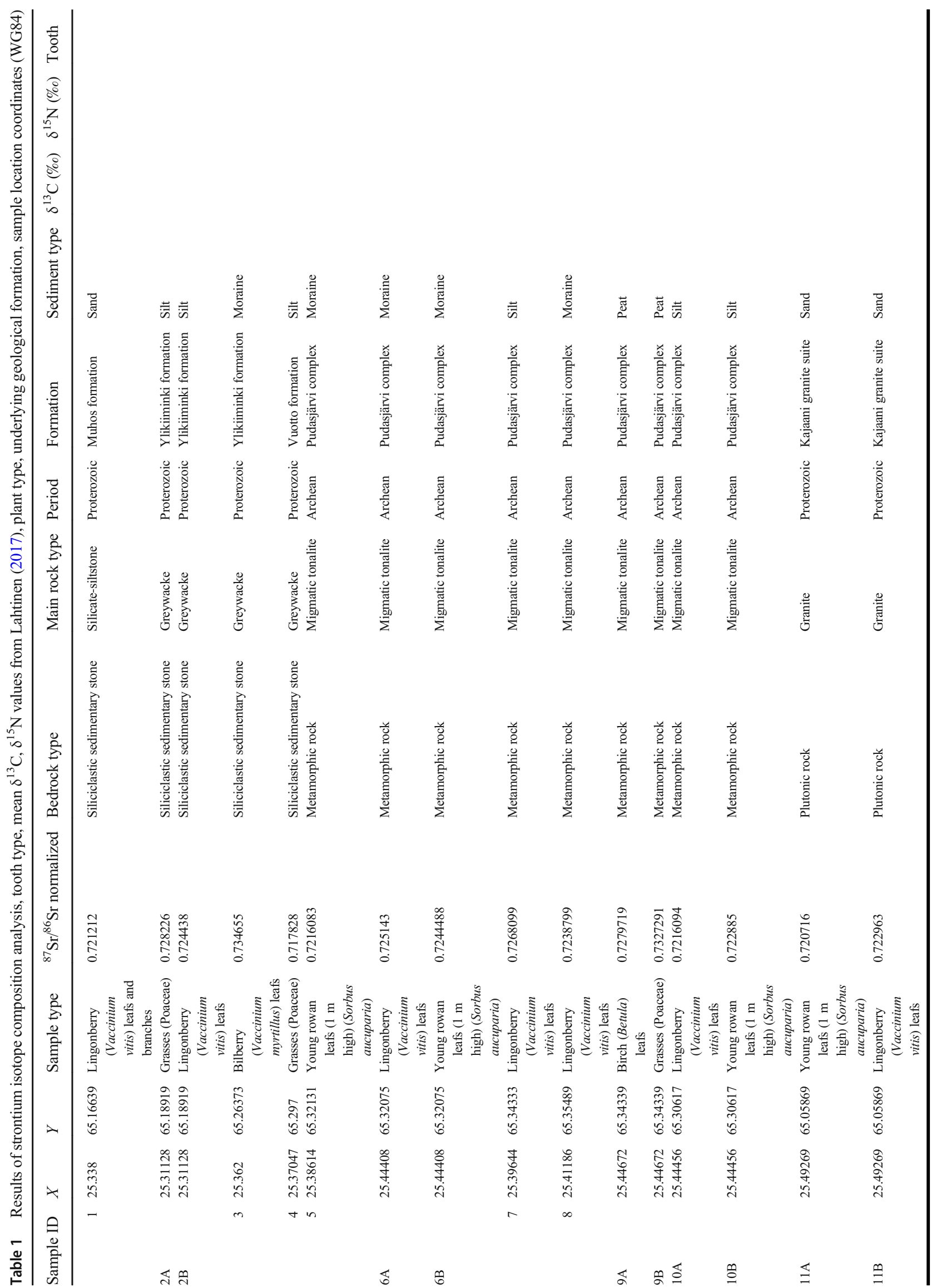




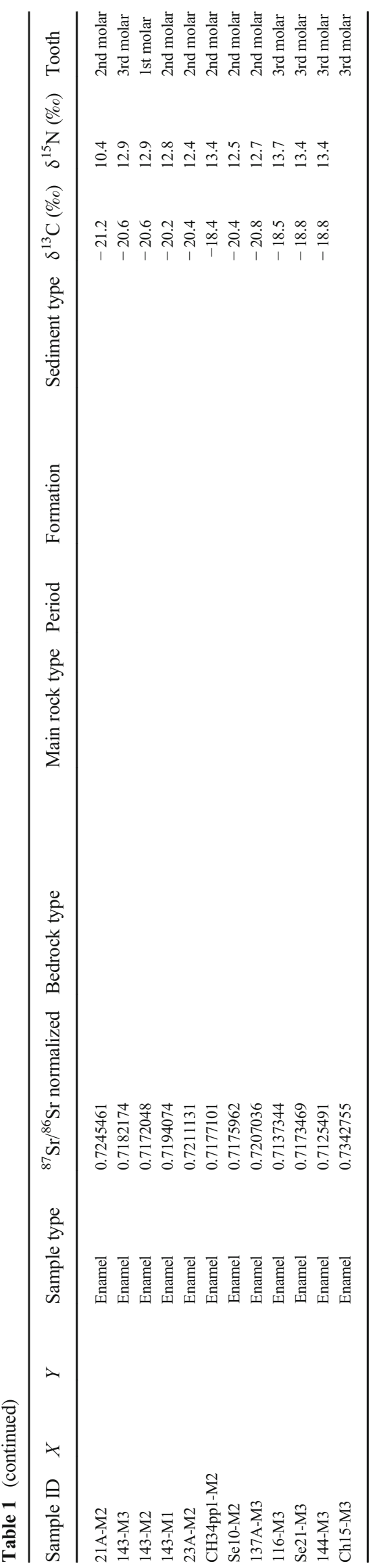

\section{Results}

The ${ }^{87} \mathrm{Sr} /{ }^{86} \mathrm{Sr}$ data are presented in Table 1 . In the plant samples, the ${ }^{87} \mathrm{Sr} /{ }^{86} \mathrm{Sr}$ ratio varied between 0.7178 and 0.7347 (mean $0.7248, \mathrm{SD} 0.0044,1 \sigma$ ). The difference between two plant sample types from a single locality ranges from 0.0007 to 0.0048 (mean 0.00076). The overall large range of plant ${ }^{87} \mathrm{Sr} /{ }^{86} \mathrm{Sr}$ values, as well as the demonstrated differences in ${ }^{87} \mathrm{Sr} /{ }^{86} \mathrm{Sr}$ ratio for different plant types growing within $1 \mathrm{~m}$ of each other, indicates a substantial level of heterogeneity in $\mathrm{Sr}$ baseline levels in the local terrestrial environment (Table 2).

Strontium isotope composition of human enamel varied between 0.7125 and 0.7343 (mean 0.7195, median 0.7180, SD 0.0056). There is one outlier among the samples, human $\mathrm{CH} 15$, whose strontium isotope ratio (0.7343) is much higher than the rest of the samples. Based on the anomalous ${ }^{87} \mathrm{Sr} /{ }^{86} \mathrm{Sr}$ value and having a very contrasting varied dentine nitrogen and carbon isotope composition, which differs from the rest of the population (Lahtinen 2017), this individual was excluded from further statistical analysis.

The correlation between mean $\delta^{13} \mathrm{C}$ and $\delta^{15} \mathrm{~N}$ values in the dentine of the sampled tooth (Lahtinen 2017), and their corresponding enamel ${ }^{87} \mathrm{Sr} /{ }^{86} \mathrm{Sr}$ ratio was tested with simple linear regression (Fig. 2). This resulted in strong negative correlations between ${ }^{87} \mathrm{Sr} /{ }^{86} \mathrm{Sr}$ ratio and $\delta^{15} \mathrm{~N}\left(r=-0.83, R^{2}=0.69\right.$, $p=0.001)$ and $\delta^{13} \mathrm{C}$ value $\left(r=-0.73, R^{2}=0.54, p=0.009\right)$, respectively. Moreover, no correlation was found with the distance from coast and isotope composition (Fig. 3).

\section{Discussion}

The ${ }^{87} \mathrm{Sr} /{ }^{86} \mathrm{Sr}$ ratio of the surveyed plants (from 0.7178 to 0.7347) and the River Ii (0.7305) (Andersson et al. 1992) combined suggest a local terrestrial ${ }^{87} \mathrm{Sr} /{ }^{86} \mathrm{Sr}$ range of 0.7178 to 0.7347 . The ${ }^{87} \mathrm{Sr} /{ }^{86} \mathrm{Sr}$ ratio from two individuals (144-M3 and 116-M3) fall distinctively below this range suggesting non-local sources of ingested Sr. It would be evident that using only these values and not information regarding the diet of these two individuals, they would be considered as immigrants. If strictly imposing the local terrestrial limits as defined by the plant sampling, the ${ }^{87} \mathrm{Sr} /{ }^{86} \mathrm{Sr}$ values of a further four individuals (143-M1, CH34pp1-M2, Se21-M3 and Se10M2) are just below the range, thus raising the total number of potential immigrants to six individuals. However, their ${ }^{87} \mathrm{Sr} /{ }^{86} \mathrm{Sr}$ values are very close to the lower limit of plantdefined local values and it is possible that our baseline sampling has not fully captured the total range of local ${ }^{87} \mathrm{Sr} /{ }^{86} \mathrm{Sr}$ values. If considering the alternative, commonly applied approach of defining local baseline as the mean \pm SD of the baseline samples (e.g. Bentley 2006; Peschel et al. 2017), our local range would expand to 0.7163-0.7347 (the upper 
Table 2 Summary of the strontium isotope composition of plants and human enamel analysed in this study

\begin{tabular}{llllllll}
\hline & Mean & Standard error & SD & Minimum & Maximum & $n$ & Range \\
\hline Plants & 0.7248 & 0.0011 & 0.0044 & 0.7178 & 0.7347 & 16 & 0.0168 \\
Enamel & 0.7195 & 0.0016 & 0.0056 & 0.7125 & 0.7343 & 12 & 0.0217 \\
\hline
\end{tabular}

end still defined by the highest value in plant samples) and the four additional individuals would fit within the local range.

A previous study has shown that people in Iin Hamina ate large proportions of fish (Lahtinen and Salmi 2019). The study shows that possibly both marine (Baltic Sea brackish) fish and fish from freshwater sources were consumed making up a high proportion of the ingested dietary protein (Lahtinen and Salmi 2019). The high level of fish consumption is observed especially as elevated $\delta^{15} \mathrm{~N}$ values in the population. Due to the generally longer food chains, aquatic prey from both marine and freshwater settings shows high $\delta^{15} \mathrm{~N}$ values compared to terrestrial animals, i.e. livestock or game (Minagawa and Wada 1984; Schoeninger et al. 1983). Thus, $\delta^{15} \mathrm{~N}$ values on their own are not very diagnostic for making distinctions between marine or freshwater fish consumption. In contrast, freshwater fish typically show much lower $\delta^{13} \mathrm{C}$ values compared to Baltic catch. Bothnian Bay modern fish carbon isotope values are from -23 to $-20 \%$ (Sinisalo et al. 2006), whereas Finnish freshwater fish typically show values well below $-25 \%$ (The DIANA database, accessed 5.5.2020;
Etu-Sihvola et al. 2019). Thus, Baltic brackish water fish consumption leads to higher $\delta^{13} \mathrm{C}$ values in human collagen compared to diets of terrestrial or freshwater resources. Moreover, Baltic Sea fish will also have a distinctly lower strontium isotope ratio than local terrestrial or freshwater dietary items. In a scenario where the composition of diet - and not simply different origins of individuals - had a significant effect determining the ${ }^{87} \mathrm{Sr} /{ }^{86} \mathrm{Sr}$ values of the Iin Hamina individuals, the Sr isotope compositions would vary in concert with their $\delta^{15} \mathrm{~N}$ and $\delta^{13} \mathrm{C}$ values. Individuals whose diets are more influenced by Baltic Sea resources should display low ${ }^{87} \mathrm{Sr} /{ }^{86} \mathrm{Sr}$ levels, high $\delta^{15} \mathrm{~N}$ values (aquatic diets in general) and high $\delta^{13} \mathrm{C}$ values (marine/brackish diets). In contrast, relatively higher ${ }^{87} \mathrm{Sr} /{ }^{86} \mathrm{Sr}$ ratios are to be expected of individuals whose diets incorporate more freshwater fish with low $\delta^{13} \mathrm{C}$ values and resources from terrestrial food chains (plants, livestock, game) lowering both $\delta^{13} \mathrm{C}$ and $\delta^{15} \mathrm{~N}$ values. Indeed, we observe a strong, negative correlation between ${ }^{87} \mathrm{Sr} /{ }^{86} \mathrm{Sr}$ ratios and both $\delta^{13} \mathrm{C}$ and $\delta^{15} \mathrm{~N}$ values (Fig. 2). Even though correlation does not prove causality, here this seems a very likely scenario and
Fig. 2 Scatter plot of human enamel strontium isotope composition and dentine collagen $\delta^{15} \mathrm{~N}$ and $\delta^{13} \mathrm{C}$ values. Grey area indicates the range of ${ }^{87} \mathrm{Sr} /{ }^{86} \mathrm{Sr}$ ratio in plant samples

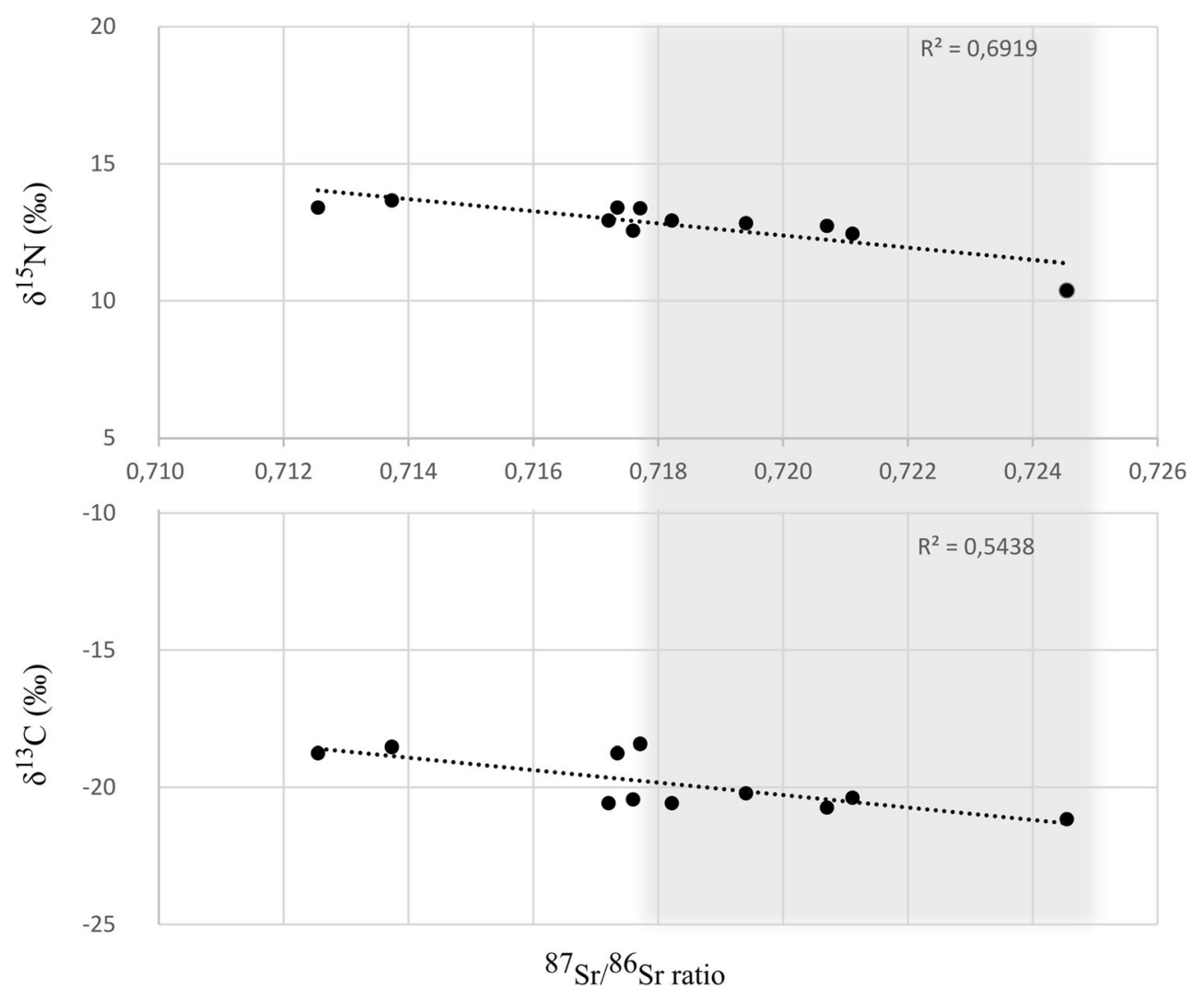


Fig. 3 Dentine mean isotope composition (Lahtinen 2017), bulk collagen isotope composition of humans skeletal remains from Iin Hamina and animals (data from Lahtinen and Salmi 2019)

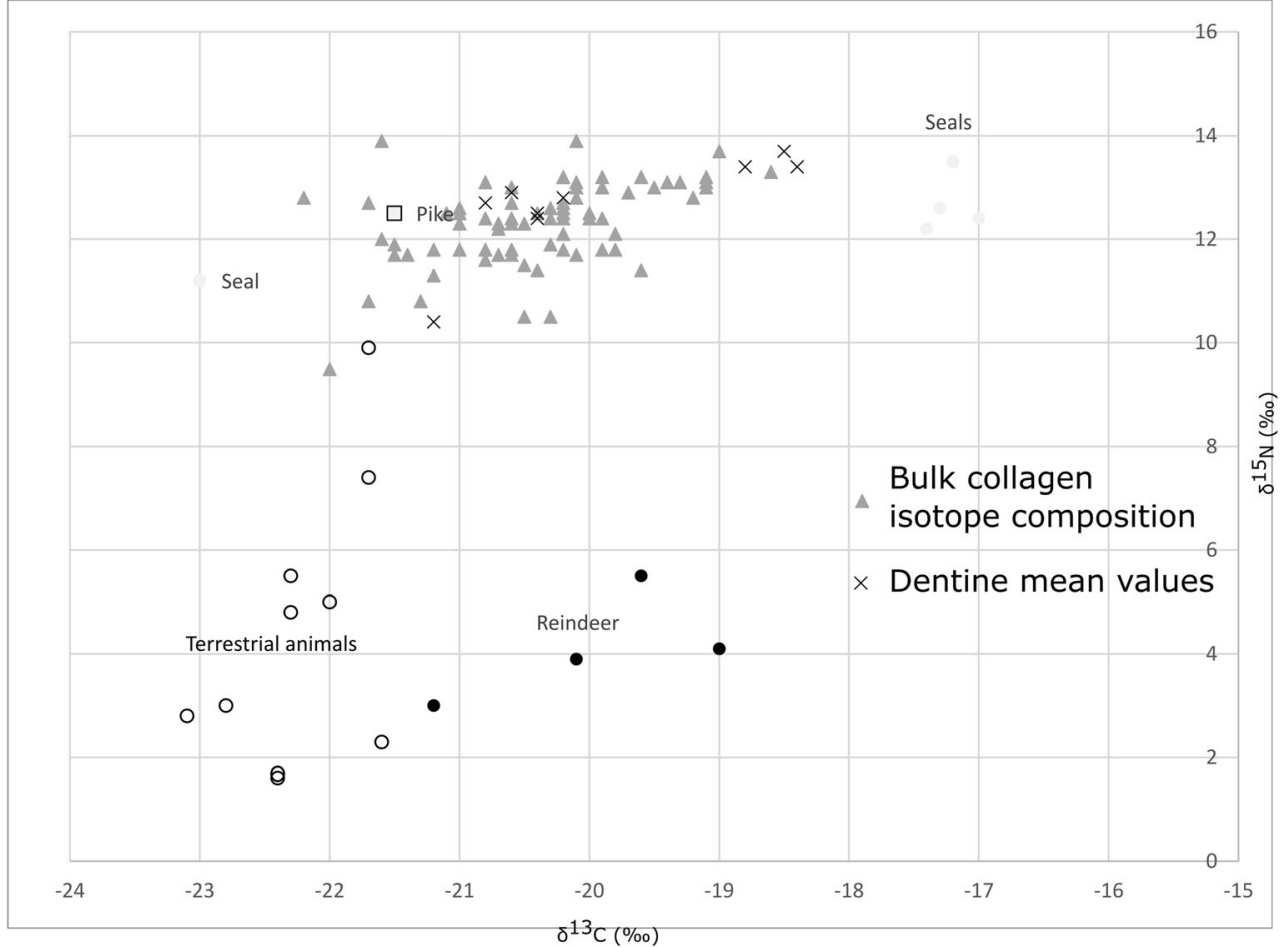

strongly suggests the composition and source of diet is the major determinant of the ${ }^{87} \mathrm{Sr} /{ }^{86} \mathrm{Sr}$ values of individuals. We note that the number of samples in this study was low, making the implications of the observed correlations more suggestive than conclusive proof of the influence of diet on ${ }^{87} \mathrm{Sr} /{ }^{86} \mathrm{Sr}$ values. If all strontium would derive simply from the terrestrial biosphere, there should not be, contrary to our results, any strong correlation between diet and strontium isotope signal. Considering all the above, we conclude that despite the two individuals showing clearly lower ${ }^{87} \mathrm{Sr} /{ }^{86} \mathrm{Sr}$ values than the local terrestrial range, it is possible that the individuals were locals, but relied on higher amounts of Baltic Sea-derived diets compared to the rest of the population.

The Sr concentration of the global oceans is typically at least one order of magnitude higher than that in freshwaters and bioavailable $\mathrm{Sr}$ in the terrestrial environment, leading to more elevated concentrations of $\mathrm{Sr}$ in marine fish. As the Baltic Sea has a Sr concentration comparable to the fresh waters in the area (see " ${ }^{87} \mathrm{Sr} /{ }^{86} \mathrm{Sr}$ background" above), the strontium concentrations in both freshwater and Baltic Sea derived fish are similar but still likely much higher than in the terrestrial environment surrounding our study site (Lill et al. 2014; Varo 1984). For example, the flesh of modern vendace (Coregonus albula), a much consumed freshwater fish in Finnish diets, has a mean $\mathrm{Sr}$ concentration of $5600 \mathrm{ppb}(5.6 \mathrm{mg} / \mathrm{kg})$. However, small fish like these are typically eaten as a whole and the fish including the bones has $12,000 \mathrm{ppb}(12 \mathrm{mg} / \mathrm{kg}$ ) of $\mathrm{Sr}$ (Varo 1984) and a $\mathrm{Sr} / \mathrm{Ca}$
0.0031. Modern cereals, on the other hand, can have Sr contents and a $\mathrm{Sr} / \mathrm{Ca}$ ratio of 400-3400 ppb (0.4-3.4 mg/kg) and 0.0012-0.0097 respectively (Varo 1984). Notably, wholegrain cereals and cereal husks have higher $\mathrm{Sr} / \mathrm{Ca}$ ratios than more processed cereals (Varo 1984). All meat has a very low strontium concentration, typically $\leq 100 \mathrm{ppb}(0.1 \mathrm{mg} / \mathrm{kg}$ (Varo 1984). This suggests that the contribution of strontium obtained from fish, even freshwater fish, can be equally high than that from cereals, which are often considered as one of the main sources of strontium for humans in Finland (Varo 1984). The contribution is potentially even more significant if fish bones are included in the diet as is common in the case of small fish species. These considerations also raise the interesting possibility of bias in human skeletal ${ }^{87} \mathrm{Sr} /{ }^{86} \mathrm{Sr}$ values. For example, it is generally recognized that carbon and nitrogen derived from relatively small supplements of animal protein are overrepresented in the $\delta^{13} \mathrm{C}$ and $\delta^{15} \mathrm{~N}$ values of bulk collagen of individuals with mainly vegetarian diets (Ambrose and Norr 1993). Along these lines, it seems possible that the ${ }^{87} \mathrm{Sr} /{ }^{86} \mathrm{Sr}$ ratios of dietary items with high $\mathrm{Sr}$ contents and $\mathrm{Sr} /$ Ca ratios, like fish, could potentially overwhelm the Sr signals of other staple dietary items of lesser $\mathrm{Sr}$ concentrations and lower $\mathrm{Sr} / \mathrm{Ca}$ ratios, even if present in much lesser quantities. We hope that future studies employing, e.g. controlled feeding experiments and state of the art metabolic modelling will tackle these questions rigorously in the future. Nevertheless, the potential of ancient populations to incorporate fish from various sources into their diets and how this would affect the total 
pool of skeletal ${ }^{87} \mathrm{Sr} /{ }^{86} \mathrm{Sr}$ values in relation to the signal expected from the local terrestrial environment should be carefully evaluated in archaeological $\mathrm{Sr}$ isotope studies.

Finally, our baseline survey of plant ${ }^{87} \mathrm{Sr} /{ }^{86} \mathrm{Sr}$ levels raises interesting additional points of consideration. The mean difference of ${ }^{87} \mathrm{Sr} /{ }^{86} \mathrm{Sr}$ ratios of plants collected from within $1 \mathrm{~m}$ of each other is 0.00076 , which is smaller compared to the standard deviation in all plant samples $(0.0044)$ or variation between different localities. This demonstrates that while different plants within close proximity $(1-2 \mathrm{~m})$ can have significant differences in ${ }^{87} \mathrm{Sr} /{ }^{86} \mathrm{Sr}$ values, perhaps linked to rooting depth, season of growth, etc., that the underlying geological units do play a significant part in controlling biologically available strontium. However, it also demonstrated that a considerably larger data set would be required for concise estimation of the biologically available strontium isotope composition of each geological unit, which we hope to be able to run in the future.

\section{Conclusions}

We show a clear correlation between diet composition and strontium isotope values in our data. It is reasonable to conclude that unlike often assumed, especially in locations that are not situated directly on the coast, not only terrestrial baselines should be used to determine what is local. Aquatic diets can substantially contribute to the strontium isotope composition of human calcified tissues. Therefore, we strongly advocate for careful evaluation of the potential, frequency and source of aquatic consumption and its expected strontium isotope composition when reconstructing past mobility using ${ }^{87} \mathrm{Sr} /{ }^{86} \mathrm{Sr}$ ratios. This is especially important when strontium isotope values of "non-locals" appear to deviate towards marine or local freshwater strontium isotope ratios.

We recommend that future ${ }^{87} \mathrm{Sr} /{ }^{86} \mathrm{Sr}$ studies should focus on the sources of strontium in human skeletal tissue in case of fish consumption. Furthermore, we hope that there will be more evidence, e.g. from controlled feeding experiments, to develop statistical tools to evaluate, in conjunction with diet reconstructions, the contributions of local terrestrial biologically available strontium and marine strontium as a starting point when evaluating peoples' status as immigrants and locals. This would be especially important during the periods, such as the Mesolithic in Europe, when significant proportions of marine foods were consumed. To facilitate more accurate ${ }^{87} \mathrm{Sr} /{ }^{86} \mathrm{Sr}$ migration studies in the future, more empirical data are needed on the effects of $\mathrm{Sr}$ contents and $\mathrm{Sr} / \mathrm{Ca}$ ratios of foodstuffs, and possible effects of, e.g. dietary preferences and $\mathrm{D}$ vitamin catalysis on skeletal incorporation of $\mathrm{Sr}$ in humans. Moreover, developed models should ultimately be sensitive to these parameters, in order to exclude non-terrestrial strontium input from the estimation of origin of people in the past before final conclusions.
In the Iin Hamina site case, with the current knowledge, we cannot unequivocally determine if the studied individuals are local or non-local, or if the skeletal ${ }^{87} \mathrm{Sr} /{ }^{86} \mathrm{Sr}$ values falling below the terrestrial baseline are due to bias towards the Baltic Sea strontium isotope composition.

Acknowledgements The authors would like to thank Paula and Kaarlo Laurikkala's hospitality and the help of Janet Montgomery during the fieldwork.

Authors' contributions Preparations and planning: M.L.; method selection and guidance: G.W.; data interpretation and writing: M.L., L.A.

Funding Open access funding provided by University of Helsinki including Helsinki University Central Hospital. M.L. was funded from Jenny and Antti Wihuri foundations and Durham University Medieval and Early Modern studies small grant.

Data availability All data produced in this study are included in the paper.

\section{Compliance with ethical standards}

Conflict of interest The authors declare that they have no conflict of interests.

Open Access This article is licensed under a Creative Commons Attribution 4.0 International License, which permits use, sharing, adaptation, distribution and reproduction in any medium or format, as long as you give appropriate credit to the original author(s) and the source, provide a link to the Creative Commons licence, and indicate if changes were made. The images or other third party material in this article are included in the article's Creative Commons licence, unless indicated otherwise in a credit line to the material. If material is not included in the article's Creative Commons licence and your intended use is not permitted by statutory regulation or exceeds the permitted use, you will need to obtain permission directly from the copyright holder. To view a copy of this licence, visit http://creativecommons.org/licenses/by/4.0/.

\section{References}

Åberg F, Wickman FE (1987) Variations of $87 \mathrm{Sr} / 86 \mathrm{Sr}$ in water from streams discharging into the Bothnian Bay, Baltic Sea. Hydrol Res 18(1):33-42. https://doi.org/10.2166/nh.1987.0003

Åberg G, Jacks G, Wickman T, Hamilton PJ (1990) Strontium isotopes in trees as an indicator for calcium availability. Catena 17(1):1-11. https://doi.org/10.1016/0341-8162(90)90011-2

Ambrose SH, Norr L (1993) Experimental evidence for the relationship of the carbon isotope ratios of whole diet and dietary protein to those of bone collagen and carbonate. In Prehistoric human bone. Springer, Berlin, Heidelberg, (pp. 1-37)

Andersson PS, Wasserburg GJ, Ingri J (1992) The sources and transport of Sr and Nd isotopes in the Baltic Sea. Earth Planet Sci Lett 113(4): 459-472. https://doi.org/10.1016/0012-821X(92)90124-E

Apostoaei I (2002) Absobtion of strontium from the gastrointestinal track into plasma in healthy human adults. Health Phys 83(1):56-65

Bentley AR (2006) Strontium isotopes from the earth to the archaeological skeleton: A Review. J Archaeol Method Theory 13(3):135-187. https://doi.org/10.1007/s10816-006-9009-x 
Bergman I, Ramqvist PH (2018) Hunters of forests and waters: Late Iron Age and medieval subsistence and social processes in Coastal Northern Sweden. Acta Borealia 35(1):1-28. https://doi.org/10. 1080/08003831.2018.1456765

Borić D, Price TD (2013) Strontium isotopes document greater human mobility at the start of the Balkan Neolithic. Proc Natl Acad Sci U S A 110(9):3298-3303. https://doi.org/10.1073/pnas.1211474110

Burton JH, Wright LE (1995) Nonlinearity in the relationship between bone $\mathrm{Sr} / \mathrm{Ca}$ and diet: paleodietary implications. Am J Phys Anthropol 96(3):273-282. https://doi.org/10.1002/ajpa. 1330960305

Capo RC, Stewart BW, Chadwick OA (1998) Strontium isotopes as tracers of ecosystem processes: theory and methods. Geoderma $82: 197-225$

Charlier BLA, Ginibre C, Morgan D et al (2006) Methods for the microsampling and high-precision analysis of strontium and rubidium isotopes at single crystal scale for petrological and geochronological applications. Chem Geol 232:114-133

Ericson JE (1985) Strontium isotope characterization in the study of prehistoric human ecology. J Hum Evol 14:503-514

Etu-Sihvola H, Bocherens H, Drucker DG, Junno A, Mannermaa K, Oinonen M, Uusitalo J, Arppe L (2019) The DIANA Database resource for isotopic paleodietary research in the Baltic Sea Area. J Archaeol Sci Rep 24(April):1003-1013. https://doi.org/10.1016/j. jasrep.2019.03.005

Fietzke J, and Eisenhauer A (2006) "Determination of temperaturedependent stable strontium isotope ( $88 \mathrm{Sr} / 86 \mathrm{Sr}$ ) fractionation via bracketing standard MC-ICP-MS." Geochem Geophys Geosyst 7 (8): n/a-n/a. https://doi.org/10.1029/2006GC001243.

Hoogewerff JA, Reimann C, Ueckermann H, Frei R, Frei KM, van Aswegen T, Stirling C et al (2019) Bioavailable $87 \mathrm{Sr} / 86 \mathrm{Sr}$ in European soils: a baseline for provenancing studies. Sci Total Environ 672(July):1033-1044. https://doi.org/10.1016/j.scitotenv. 2019.03.387

Kaislaniemi L (2011) Estimating the distribution of strontium isotope ratios ( $87 \mathrm{Sr} / 86 \mathrm{Sr}$ ) in the Precambrian of Finland. Bull Geol Soc Finl 83:95-113

Kallio-Seppä, Titta (2010) "IIN HAMINA Yläkadun kunnostustyöt. Hautausmaan arkeologinen koe- ja pelastuskaivaus (25.5.3.7.2009) sekä seuranta (elo-syyskuu 2009)." Finnish Heritage Agency.

Kallio-Seppä T (2011) Tietoa Iin Kirkosta Ja Kirkkomaista Kirjallisten Ja Arkeologisten Lähteiden Perusteella. In Iin Haminan Kirkko Ja Hautausmaa - Arkeologisia Tutkimuksia:34-43

Kallio-Seppä, Titta, Juho-Antti Junni, Sirpa Niinimäki, Hanna-Kaisa Korpi, Terhi Tanskanen, Tiina Heikkilä, and Kaija Kamula (2009) "Excavation at Ii Hamina Discontinued Cemetery - Preliminary Results and Implication." Fennoscandia Archaeologica XXVI: $172-176$.

Klusek CS (1984) "Strontium-90 in the U.S. Diet, 1982.” EML Reports 429.

Kylli R (2005) Kirkon Ja Saamelaisten Kohtaaminen Utsjoella Ja Inarissa 1742-1886. Studia Historica Septentrionalia 25

Kylli R (2012) Saamelaisten Kaksi Kääntymystä: Uskonnon Muuttuminen Utsjoen Ja Enontekiön Lapinmailla 1602-1905. Historiallisia Tutkimuksia 259

Lahtinen M (2017) Isotopic evidence for environmental adaptation in Medieval Iin Hamina, Northern Finland. Radiocarbon 59(4):11171131. https://doi.org/10.1017/RDC.2017.52

Lahtinen M, Salmi A-K (2019) Mixed livelihood society in Iin Hamina a case study of medieval diet in the Northern Ostrobothnia, Finland. Environ Archaeol 24(1):1-14. https://doi.org/10.1080/14614103. 2018.1444695

Lahtinen M, Salmi A-K, Vilkama R (2013) Ruoanjätteitä, Kariesta Ja Kemiaa : Miten Arkeologiset Ja Luonnontieteelliset Menetelmät
Kertovat Ruokapöydän Antimista 1400-1700-Luvulla. Historiallinen Aikakausikirja 4:409-421

Lamb AL, Evans JE, Buckley R, Appleby J (2014) Multi-isotope analysis demonstrates significant lifestyle changes in King Richard III. J Archaeol Sci 50(October):559-565. https://doi.org/10.1016/j.jas. 2014.06.021

Lill J-O, Himberg M, Harju L, Ek P, Lindroos A, Wiklund T, Gunnelius K, Smått J-H, Heselius S-J, Hägerstrand H (2014) Strontium and zinc concentrations in otoliths of common fish species in the Northern Baltic Sea. Nucl Instrum Methods Phys Res, Sect B 318(January):109-112. https://doi.org/10.1016/j.nimb.2013.05.096

Linderholm A, Andersson K, Mörth C-M, Grundberg L, Haarding B, Lindén K (2008) An early Christian cemetery at Björned in Northern Sweden: stable isotope analyses of skeletal material. Fornvännen 103:176-189

Löfvendahl R, Aberg G, Joseph Hamilton P (1990) Strontium in rivers of the Baltic Basin. Aquat Sci 52(4):1015-1621

Minagawa M, Wada E (1984) Stepwise enrichment of $15 \mathrm{~N}$ along food chains: further evidence and the relation between $\delta 15 \mathrm{~N}$ and animal age. Geochim Cosmochim Acta 48(5):1135-1140

Montgomery J (2010) Passports from the past: investigating human dispersals using strontium isotope analysis of tooth enamel. Ann Hum Biol 37(3):325-346. https://doi.org/10.3109/03014461003649297

Muller W (2003) Origin and migration of the Alpine Iceman. Science 302(5646):862-866. https://doi.org/10.1126/science.1089837

Nier AO (1938) The isotopic constitution of strontium, barium, bismuth, thallium and mercury. Phys Rev 54(4):275-278. https://doi.org/10. 1103/PhysRev.54.275

Peschel EM, Carlsson D, Bethard J, Beaudry MC (2017) Who resided in Ridanäs? A study of mobility on a Viking Age Trading Port in Gotland, Sweden. J Archaeol Sci Rep 13(June):175-184. https:// doi.org/10.1016/j.jasrep.2017.03.049

Price TD, Swick RW, Chase EP (1986) Bone chemistry and prehistoric diet: strontium studies of laboratory rats. Am J Phys Anthropol 70(3):365-375. https://doi.org/10.1002/ajpa.1330700311

Schoeninger MJ, DeNiro MJ, Tauber H (1983) Stable nitrogen isotope ratios of bone collagen reflect marine and terrestrial components of prehistoric human diet. Science 220(4604):1381-1383

Sillen A, Kavanagh M (1982) Strontium and paleodietary research: a review. Am J Phys Anthropol 25(S3):67-90. https://doi.org/10. 1002/ajpa.1330250505

Sinisalo T, Valtonen ET, Helle E, Jones RI (2006) Combining stable isotope and intestinal parasite information to evaluate dietary differences between individual ringed seals (Phoca Hispida Botnica). Can J Zool 84:823-831. https://doi.org/10.1139/Z06-067

Steiger RH, Jäger E (1977) Subcommission on geochronology: convention on the use of decay constants in geo- and cosmochronology. Earth Planet Sci Lett 36(3):359-362. https://doi.org/10.1016/0012821X(77)90060-7

Tanska T (2011) Asutus Ja Kaupankäyntiä Iijoella. In Iin Haminan Kirkko Ja Hautausmaa - Arkeologisia Tutkimuksia:25-31

Tolstykh EI, Degteva MO, Peremyslova LM, Shagina NB, Shishkina EA, Krivoshchapov VA, Anspaugh LR, Napier BA (2011) Reconstruction of long-lived radionuclide intakes for techa riverside residents: strontium-90. Health Phys 101(1):28-47. https://doi.org/ 10.1097/HP.0b013e318206d0ff

Vahtola J (1998) Katollisen Kirkon Ja Uskonpuhdistuksen Aika (Noin 1350 - 1595). In Iin Seurakunnan Historia:13-50

Varo P (1984) Kivennäisaine Taulukko. 1984. Otava.

Publisher's note Springer Nature remains neutral with regard to jurisdictional claims in published maps and institutional affiliations. 